\title{
Activity of proteolytic enzymes during Provolone and Montasio cheese ripening
}

\author{
by \\ P. SPETTOLI and A. ZAMORANI
}

\section{S u m m a ry}

Acid and neutral protease, aminopeptidase, carboxypeptidase and acid phosphatase activities during Provolone and Montasio cheese ripening have been evaluated. The levels of acid and neutral protease activities have nearly an alike trend in Provolone and Montasio cheese samples. The former remains constant, while the latter increases. The aminopeptidase activity in Provolone cheese increases during the ageing from 15 to 105 days and it successively decreases. The carboxypeptidase activity shows a continuous decrease in Provolone cheese and it disappeared in Montasio cheese. Finally, the values of acid phosphatase activity decline during the ripening of two cheses.

Key words

Proteolytic enzymes - Cheese ripening - Provolone - Montasio.

\section{Rés u mé}

ACTIVITÉ DES ENZYMES PROTÉOLYTIQUES AU COURS DE L'AFFINAGE du fromage de Provolone et de Montasio

Les activités protéasiques, mesurées à $p H$ acide et neutre, ainsi que les activités aminopeptidasique, carboxypeptidasique et phosphatasique ont été étudiées au cours de l'affinage du fromage de Provolone et de Montasio. Les activités protéasiques montrent un comportement équivalent dans les deux fromages, l'activité à $p H$ acide est stable pendant que celle à pH neutre augmente. Un accroissement de l'activité des aminopeptidases est observé dans l'affinage de Provolone jusqu'au $105^{\mathrm{e}}$ jour, ensuite on note une diminution. L'activité car-

Istituto di Chimica Agraria e Industrie Agrarie, Via Gradenigo, 6 - 35100 Padova, Italia. 
boxypeptidasique manifeste une disparition progressive dans le Provolone qui devient nulle au cours de l'affinage de Montasio. Enfin, l'activité phosphatasique diminue progressivement dans la maturation des deux fromages considérée.

Mots clés

Enzymes protéolytiques - Affinage des fromages - Provolone - Montasio.

\section{INTRODUCTION}

Cheese ripening involves several reactions in the curd, which are the decomposition and resynthesis of all compounds such as proteins, peptides, aminoacids, carbohydrates, lipids, nucleic acids, organic acids, carbonyl compounds, growth factors from the groups of vitamins, prosthetic group of enzymes and simple decomposition products, such as carbon dioxide and ammonia (Schormüller, 1968). The above chemical changes are catalyzed by the enzymes of microorganisms involved in the ripening or derived from commercial rennet preparations and to a limited extent from milk (Desmazeaud and Gripon, 1977). Enzyme systems of specific microorganisms which are important in cheese technology have been studied in detail (Bolcato et al., 1973 ; Law et al., 1974 ; Castberg and Morris, 1976 ; Gripon et al., 1977). On the contrary studies on specific enzyme activities in cheese are scanty. Camus and Alifax (1951) detected alkaline phosphatase in ripened Camembert cheese, which was preferably located in the rind. Schormüller et al. (1954) showed the occurrence of proteinases in ripening sour milk cheese ; the same authors later showed dipeptidases, aminopeptidases and carboxypeptidases (Schormüller et al., 1955). Data are available on peptidase groups for cheese ripening, particularly the specific enzymes prolinase and prolidase (Schormüller and Müller, 1955, 1957). Schormüller and Lahmann (1956) evaluated the distribution of alkaline and acid phosphatases in different parts of cheeses too. Kiermeier et al. (1961), studying phosphatase activity in cheese, showed that the alkaline phosphatase occurred in ripened Camembert cheese and other cheese varieties as Edam, Romadur, Tilsiter. Law et al. (1974), studying the levels of dipeptidase activities during Cheddar cheese ripening, showed that part of the activity was sufficiently stable to persist at least 120 days. Andrews and Alichanidis (1975), investigating the acid phosphatase activity in Greek cheeses of various types and in Cheddar cheeses, founded it was unaffected by storage for up to 18 months and 12 months, respectively. On the other hand, even if the phenomena occurring during cheese ripening are very complex and less controlled, the problem of enzyme activities in ripened cheeses during storage is to point out (Gripon et al., 1977).

Our aim is to study the role of proteolytic enzymes in cheese ripening ; it could be possible to obtain enzymatic data for trying an analytical typification of the cheeses. This paper is an attempt at 
providing some information about acid and neutral protease, aminopeptidase, carboxypeptidase and acid phosphatase activities in two semi-hard Italian cheeses, Montasio and Provolone, during an extent of ripening of 2 and 6 months, respectively.

\section{MATERIALS AND METHODS}

\section{Cheese manufacture}

Cheeses were manufactured at a commercial dairy plant producing Montasio and Provolone according to conventional italian procedures (Rossi, 1977).

\section{Montasio cheese}

Raw milk was heated at $33-34^{\circ} \mathrm{C}$ and sufficient rennet was added so that the curd could be cut after 20-30 min. Following coagulation, the curd was cut and cooked at $44-45^{\circ} \mathrm{C}$. Then the whey was removed and the cheese was pressed and salted in $18 \%$ brine for about 18-24 hours, and stored up in a $15^{\circ} \mathrm{C}, 80 \%$ relative humidity (R.H.) ripening room. We analyzed curd and cheese samples after 1 and 2 months of ageing.

\section{Provolone cheese}

Refrigerated raw milk was heated at $60-62^{\circ} \mathrm{C} / 6 \mathrm{sec}$, then its temperature was adjusted to $37^{\circ} \mathrm{C}$ and $2 \%$ previous manufacture whey was added as natural starter. Paste kid rennet was used so that the curd could be cut after 10-12 min. Following coagulation, the curd was cut and cooked for about $8 \mathrm{~min}$ at $50^{\circ} \mathrm{C}$. The curd was removed from the whey and placed on trays for 4-5 hours in a ripening room. When the $\mathrm{pH}$ reached 4.85 it was hand-drawn in water at $70^{\circ} \mathrm{C}$. Then the curd was cooled in water, salted, placed in a $23-25^{\circ} \mathrm{C}, 55-60 \%$ R.H. room for approximately 4 to 5 days and stored up in a $13-15^{\circ} \mathrm{C}$, $80 \%$ R.H. ripening room for 6 to 8 months. Provolone cheese samples were analyzed after $0.5,1,3,5$ and 6 months of ageing.

\section{Enzyme extraction and assay}

Cheese samples $(20 \mathrm{~g})$ were homogenized with an Ultra-Turrax apparatus in $50 \mathrm{ml}$ ice-cold $0.01 \mathrm{M}$ citrate buffer $\mathrm{pH}$ 6.0. The slurry was centrifugated at $4^{\circ} \mathrm{C}$ and $12.000 \mathrm{~g}$ for $10 \mathrm{~min}$ and then filtered through Whatman 4. The filtrate was used for enzymatic assay.

Acid and neutral protease activities were measured as reported by Paquet and Gripon (1980) at pH 4.0 (hemoglobin substrate) and $\mathrm{pH}$ 7.5 (casein substrate). Aminopeptidase activity was determined at pH 7.5 on leucine-p-nitroanilide (LNA) (Desmazeaud et Juge, 1976). 
TABLE 1 - TABLEAU 1

Variation of enzymatic activities in Montasio cheese during ripening. The activities of acid neutral protease, aminopeptidase and carboxypeptidase are expressed in terms of $\Delta$ O.D. $/ \mathrm{h} / \mathrm{g}$ of cheese at $37^{\circ} \mathrm{C}$ at 280,400 and $410 \mathrm{~nm}$, respectively, in the assay conditions. The activity of acid phosphatase is expressed in terms of $\mu g$ p-nitrophenol/h/g of cheese at $37^{\circ} \mathrm{C}$ in the assay conditions.

Activités enzymatiques au cours de l'affinage du fromage de Provolone. Les activités de la protéase acide et de la protéase neutre, de l'aminopeptidase et de la carboxypeptidase sont exprimées par la mesure des variations de densité optique $\left(\Delta\right.$ O.D.) $/ \mathrm{h} / \mathrm{g}$ du fromage à $37^{\circ} \mathrm{C}$ à 280,400 et $410 \mathrm{~nm}$ respectivement dans les conditions de $1^{\prime}$ essai. L'activité de la phosphatase acide est exprimée en $\mu \mathrm{g}$ de p-nitrophénol libéré/h/g de fromage à $37^{\circ} \mathrm{C}$ dans les conditions de l'essai.

\begin{tabular}{|c|c|c|c|c|c|}
\hline $\begin{array}{l}\text { Ripening time } \\
\text { in days }\end{array}$ & $\begin{array}{c}\text { Acid protease } \\
\mathrm{pH} 4.0\end{array}$ & $\begin{array}{l}\text { Neutral protease } \\
\qquad \mathrm{pH} 7.5\end{array}$ & $\begin{array}{l}\text { Acid phosphatase } \\
\text { pH } 5.0\end{array}$ & $\begin{array}{c}\text { Aminopeptidase } \\
\text { pH } 7.5\end{array}$ & $\begin{array}{c}\text { Carboxypeptidase } \\
\text { pH } 6.5\end{array}$ \\
\hline 15 & $0.116^{a}$ & $0.085^{c}$ & $8.08^{a}$ & $1.01^{c}$ & $0.213^{a}$ \\
\hline 30 & $0.140^{\mathrm{a}}$ & $0.075^{c}$ & $4.68^{b}$ & $0.87^{c}$ & $0.186^{\mathrm{b}}$ \\
\hline 105 & $0.113^{a}$ & $0.143^{b}$ & $2.23^{c}$ & $2.78^{a}$ & $0.088^{c}$ \\
\hline 180 & $0.131^{a}$ & $0.173^{\mathrm{a}}$ & $2.44^{\mathrm{C}}$ & $1.68^{\mathrm{b}}$ & $0.026^{d}$ \\
\hline \multicolumn{6}{|c|}{$\begin{array}{l}\text { All enzymatic activity measures were average of eight samples. } \\
\text { Differences between age in days were measured by Duncan's New Multiple Range Test. } \\
a, b, c, d \text {. }\end{array}$} \\
\hline
\end{tabular}


$T A B L E 2-T A B L E A U 2$

Variation of enzymatic activities in Montasio chesse during ripening. The activities of acid neutral protease, aminopeptidase and carboxypeptidase are expressed in terms of $\Delta O . D . / \mathrm{h} / \mathrm{g}$ of cheese at $37^{\circ} \mathrm{C}$ at 280,400 and $410 \mathrm{~nm}$, respectively, in the assay conditions. The activity of acid phosphatase is expressed in terms of $\mu \mathrm{g}$-nitrophenol/h/g of cheese at $37^{\circ} \mathrm{C}$ in the assay conditions.

Activités enzymatiques au cours de l'affinage du fromage de Montasio. Les activités de la protéase acide et de la protéase neutre, de l'aminopeptidase et de la carboxypeptidase sont exprimées par la mesure des variations de densité optique $\left(\Delta\right.$ O.D.) $/ \mathrm{h} / \mathrm{g}$ du fromage à $37^{\circ} \mathrm{C}$ à 280,400 et $410 \mathrm{~nm}$ respectivement dans les conditions de l'essai. L'activité de la phosphatase acide est exprimée en $\mu \mathrm{g}$ de p-nitrophénol libéré/h/g de fromage à $37^{\circ} \mathrm{C}$ dans les conditions de l'essai.

\begin{tabular}{|c|c|c|c|c|c|}
\hline $\begin{array}{c}\text { Comparison of age } \\
\text { in days }\end{array}$ & $\begin{array}{c}\text { Acid protease } \\
\text { pH } 4.0\end{array}$ & $\begin{array}{c}\text { Neutral protease } \\
\mathrm{pH} 7.5\end{array}$ & $\begin{array}{c}\text { Acid phosphatase } \\
\text { pH } 5.0\end{array}$ & $\begin{array}{c}\text { Aminopeptidase } \\
\mathrm{pH} 7.5\end{array}$ & $\begin{array}{c}\text { Carboxypeptidase } \\
\text { pH } 6.5\end{array}$ \\
\hline 0 (curd) & 0.182 & 0.107 & 13.01 & 0.444 & 0.352 \\
\hline \multicolumn{6}{|l|}{ Vs. } \\
\hline $30-60$ & 0.192 & 0.166 & 12.53 & 0.353 & 0 \\
\hline 30 & 0.130 & 0.071 & 13.62 & 0.425 & 0 \\
\hline \multicolumn{6}{|l|}{ Vs. } \\
\hline \multirow[t]{2}{*}{60} & 0.255 & 0.262 & 11.45 & 0.282 & 0 \\
\hline & ** & $* *$ & $* *$ & $* *$ & \\
\hline $\begin{array}{l}\text { All enzymatic acti } \\
\text { N.S. = not signif } \\
* * \quad=\text { significant }\end{array}$ & $\begin{array}{l}\text { y measures were } \\
\text { t } \\
\text { the } 0.01 \text { level }\end{array}$ & $\begin{array}{l}\text { rage of eight sam } \\
\text { probability }\end{array}$ & & & \\
\hline
\end{tabular}


Carboxypeptidase activity was detected by the amount of p-nitroanilide liberated during the enzyme hydrolysis of benzoyl-L-tyrosine p-nitroanilide (BTPNA) (Hayashi, 1976). Acid phosphatase activity was evaluated in $0.1 \mathrm{M}$ acetate buffer at $\mathrm{pH} 5.0$, using p-nitrophenylphosphate as substrate (Bingham and Zittle, 1963). Merthiolate was added to the reaction mixtures placed in a water-shaking incubator at $37^{\circ} \mathrm{C}$ for a suitable time of incubation.

\section{RESULTS AND DISCUSSION}

The levels of enzyme activities in Provolone and Montasio cheese during ripening are shown in tab. 1 and 2, respectively. The acid and neutral protease activities in Provolone cheese are differentiated on the basis of their behaviour against age in days. The former remains constant, while the latter increases (tab. 1). The values of the same activities have nearly an alike trend in comparison of age in days in Montasio cheese samples (tab. 2). Lenoir and Auberger (1982) studied the activity of acid and neutral protease in Camembert cheese ripening. The two activities were low and showed little changes in the core, while in the rind the acid protease activity disappeared after about 20 days of ripening since the $\mathrm{pH}$ of the medium increased too. Thus the action of neutral protease was considered important in protein breakdown during Camembert ripening. Therefore, our data would indicate the acid protease besides the neutral protease might play an equal role in Provolone and Montasio cheese ageing. The aminopeptidase activity in Provolone cheese samples increases during the ageing from 15 to 105 days $(\Delta$ O.D. $1.01 / \mathrm{h} / \mathrm{g}$ and $\Delta$ O.D. 2.78 / $\mathrm{h} / \mathrm{g}$, respectively) and it successively decreased to $\Delta$ O.D. $1.68 / \mathrm{h} / \mathrm{g}$ after 180 days of. ripening (tab. 1). On the contrary, in Montasio cheese samples it decreases in comparison of age to zero (curd) vs. 30-60 days $(\Delta$ O.D. $0.444 / \mathrm{h} / \mathrm{g}$ to $\Delta$ O.D. $0.353 / \mathrm{h} / \mathrm{g}$, and $\Delta$ O.D. $0.425 /$ $\mathrm{h} / \mathrm{g}$ to $\Delta$ O.D. $0.282 / \mathrm{h} / \mathrm{g}$, respectively) (tab. 2). The behaviour of aminopeptidase activity in Provolone and Montasio cheese samples seems in agreement with the results obtained by Law et al. (1974) in extracts of Cheddar cheese during maturation. The carboxypeptidase (optimum $\mathrm{pH}$ 6.5) falls from $\Delta$ O.D. $0.213 / \mathrm{h} / \mathrm{g}$ to $\Delta$ O.D. $0.026 / \mathrm{h} / \mathrm{g}$ in Provolone cheese (tab. 1) and it disappeared in Montasio cheese (tab. 2). Schormüller et al. (1955) demonstrated a carboxypeptidase activity in sour milk cheese with a pH optimum 7.0-7.2. However, we used the method based on determining the amount of p-nitroanilide liberated during the enzyme hydrolysis of BPTNA. This was accomplished to prevent the ninhydrin-positive and ultraviolet absorbing compounds which are present in large amounts in cheese extracts. The above enzymatic activity is now designated carboxypeptidase $\mathrm{Y}$ to distinguish it from similar enzymes as the pancreatic carboxypeptidases A and B. Peptidase supply the " pool " of free amino acids which, 
through oxidative, reductive, or hydrolytic deamination, along with decarboxylation and some other processes, yield many flavour compounds (Schormüller, 1968). Phosphatases might play an important role in some of the above processes. In this respect, we determined acid phosphatase in Provolone and Montasio cheese samples during their ageing. The levels of acid phosphatase activity decreases from $8.08 \mu \mathrm{g}$ p-nitrophenol $/ \mathrm{h} / \mathrm{g}$ to $2.44 \mu \mathrm{g}$ p-nitrophenol $/ \mathrm{h} / \mathrm{g}$ in Provolone 15 days and 180 days old, respectively (tab. 1), whereas it remains unchanged in comparison of age from curd to 30-60 days of Montasio cheese or it slightly declines from $13.6 \mu \mathrm{g} \mathrm{p}$-nitrophenol $/ \mathrm{h} / \mathrm{g}$ to $11.45 \mu \mathrm{g}$ p-nitrophenol $/ \mathrm{h} / \mathrm{g}$ in comparison of cheese samples 30 vs. 60 days (tab. 2). Our results for Montasio cheese are partially in agreement with data presented by Andrews and Alichanidis (1975), whereas the acid phosphatase activity in Provolone cheese would behave as the alkaline phosphatase in sour milk cheese (Schormüller and Lahmann, 1956) or in Camembert and Brie (Veisseyre, 1979).

The texture and the flavour characteristics of a mature cheese result, in almost all cheese varieties, from the degradation of the cheese proteins through enzymatic activities. It seems that flavour compounds are not produced by the metabolic processes of viable cells, but by enzymes surviving in the cheese after the death and lysis of the cells (Law et al., 1974). In Provolone cheese manufacture a natural starter lactic acid bacteria was added to obtain a more homogeneous ripening of the curd (Rossi, 1977). It has been reported that proteinases and peptidases from starter bacteria seem to be mainly responsible for the liberation of amino acids during maturation of Cheddar and Gouda cheese, even if this has not been unequivocally established during Cheddar cheese ripening (O'Keefe et al., 1978). The assessment of the contribution of starter bacteria to formation of small peptides in cheese is complicated by the activity of the coagulant and non-starter bacteria (O'Keefe et al., 1978). Furthermore, the extrapolation of proteolytic activity data measured in different systems than cheese ones may be without value since often suboptimal conditions for the proteinases and peptidases are existing in cheese (Castberg and Morris, 1976). Therefore it appears very important to obtain further information on the activity of proteolytic enzymes since we still understand very little about the mechanisms which lead to a good quality cheese (Adda et al., 1982).

\section{Acknowledgment}

The authors are grateful to Mrs. Maria L. Morandi for skillful technical assistance.

Research work supported by C.N.R., Italy, special grant I.P.R.A., subproject 3, Paper n. 338. 


\section{References}

ADDA (J.), GRIPON (J.C.), VASSAL (L.) (1982). - The chemistry of flavour and texture generation in cheese. Food Chemistry, 9, 115.

ANDrews (A.T.), ALICHANidis (E.) (1975), - Acid phosphatase activity in cheese and starters. J. Dairy Res., 42, 327.

Bingham (E.W.), ZITTLE (C.A.) (1963). - Purification and properties of acid phosphatase in bovine milk. Arch. Biochem. Biophys,, 101, 471.

Bolcato (V.), Spettoli (P.), Dal Belin Peruffo (A.) (1973). - Amino acid regulation of proteases of some Penicillia of Gorgonzola cheese and of Streptococcus lactis and Lactobacillus casei. Milchwissenschaft, 28, 225.

Camus (A.), Alifax (R.) (1951). - Le test de la phosphatase appliqué à la recherche de la pasteurisation des laits de fromagerie. Lait, 31, 367.

CAstberg (H.B.), Morris (H.A.) (1976). - Degradation of milk proteins by enzymes from lactic acid bacteria used in cheese making. A review. Milchwissenschaft, 31, 85.

Desmazeaud (M.J.), Juge (M.) (1976). - Caractérisation de l'activité protéolytique et fractionnement des dipeptidases et des aminopeptidase de Streptococcus thermophilus. Lait, 56, 241.

DesmazeAud (M.J.), GRIPON (J.C.) (1977). General mechanism of protein breakdown cheese ripening. Milchwissenschaft, 32, 731.

Gripon (J.C.), Desmazeaud (M.J.), Le Bars (D.), Bergère (J.L.) (1977). - Role of proteolytic enzymes of Streptococcus lactis, Penicillium roqueforti and Penicillium caseicolum during cheese ripening. J. Dairy Sci., 60, 1532.

Hayashi (R.) (1976). - Carboxypeptidase y in " Methods in Enzymology ", edited by Lorand L., Academic Press Inc., Vol. XLV, San Francisco, London.

KiERMEIER (F.), FAHMY (T.K.), KERN (R.) (1961). - Untersuchungen zur Kenntnis der Phosphateaktivität in Käse. Z. Lebnsm. Untersuch. u. - Forsch., 114, 203.

LAW (B.A.), SHARPE (M.E.), ReITER (B.) (1974), - The release of intracellular dipeptidase from starter streptococci during Cheddar cheese ripening. $J$. Dairy Res., 41, 137.

LeNOiR (P.), AUbERGer (B.) (1982). - Activity of acid and neutral protease of Penicillium caseicolum in Camembert cheese ripening. XXI Intern. Dairy Congress, p. 336, Moscow.

O'KeEFe (A.M.), FoX (P.F.), Daly (C.) (1978), - Proteolysis in Cheddar cheese : role of coagulant and starter bacteria. J. Dairy Res., 45, 465.

PAQUET (J.), GRIPON (J.C.) (1980). - Intracellular peptide hydrolases of Penicillium roqueforti. Milchwissenschaft, 35,72 .

Rossi (G.) (1977). - Manuale di tecnologia casearia, ed. Edagricole, 2a ed., Bologna.

SchormüilleR (J.), WIESKe (R.), Winter (H.) (1954). - Beiträge zur Biochimie der Käsereifung. VIII. Mitt. Die Proteinasen des Sauermilchkäses und deren Aktivität im Verlauf der Reifung. Z. Lebensm. Untersuch. u. - Forsch., 99, 437.

Schormüller (J.), MülleR (H.) (1955), - Beiträge zur Biochemie der Käsereifung. XII. Mitt Uber die Spaltung synthetischer Prolypeptide durch Prolinase aus Sauermilchkäse. Z. Lebensm. Untersuch. u. - Forsch., 100, 380.

SCHORMüller (J.), WieSke (R.), WinTer (H.) (1955), - Beiträge zur Biochemie der Käsereifung. IX. Mitt die Peptidasen des Sauermilchkäses und deren Aktivität im Verlauf der Reifung. Z. Lebensm. Untersuch. u. - Forsch., 100, 35.

SCHORmülleR (J.), LAHMANN (E.) (1956). - Beiträge zur Biochemie der Käsereifung. XVI. Mitt. Die Phosphatasensysteme des Sauermilchkäses und ihre Entwicklung während der Reifung. Z. Lebensm. u-Forsch., 103, 211.

SchormüllleR (J.), MüLlER (H.) (1957). - Beiträge zur Biochemie der Käsereifung. XIX. Mitt. über die Bestimmung und Kennzeichnung der Prolidase in Sauermilchkäse. Z. Lebensm. u. -Forsch, 105, 39.

SCHORMülleR (J.) (1968). - The chemistry and biochemistry of cheese ripening. Adv. Food Res., 16, 231.

VEISSEYRE (R.) (1979). - Principes fondamentaux de la technologie des fromages. In « Technologie du lait ", éd. par La Maison Rustique, $3^{\mathrm{R}}$ édition, Paris. 